\title{
EKSPLORASI RESISTENSI NYAMUK AEDES SP DENGAN METODE SUSCEPTIBILITY MENGGUNAKAN INSEKTISIDA MALATHION 0,8\% DAN LAMDACYHALOTRIN 0,03\%
}

\author{
Liyana Azizatul Muadibah $^{1)}$, Aris Santjaka ${ }^{2)}$, Mela Firdaust ${ }^{3)}$ \\ DKK Kebumen, Poltekkes Kemenkes Semarang, Poltekkes Kemenkes Semarang
}

\begin{abstract}
Abstrak
Latar Belakang demam Berdarah Dengue disebabkan oleh salah satu dari empat antigen yang berbeda, tetapi sangat dekat satu dengan yang lain. Insektisida digunakan dalam pengendalian vektor secara kimiawi, tetapi cara ini menyebabkan nyamuk menjadi resisten. Tujuan penelitian mengetahui status resistensi nyamuk Aedes $S p$ sebagai vektor utama DBD di Desa Kedungrandu Kecamatan Patikraja dan di Desa Sidamulih Kecamatan Rawalo Kabupaten Banyumas terhadap insektisida Malathion 0,8\% dan Lamdacyhalotrin 0,03\%. Jenis penelitian eksplorasi. Hasil penelitian menggunakan metode Susceptibility test dengan insektisida Malathion 0,8\% di Desa Kedungrandu Kecamatan Patikraja menunjukkan prosentase kematian sebesar 8,75\%, dan di Desa Sidamulih adalah 15\% dan 11,25\%. Sedangkan Lamdacyhalotrin 0,03\% di Desa Kedungrandu adalah 100\%, dan di Desa Sidamulih adalah 92,5\%. Disimpulkan terjadi resisten di kedua desa terhadap Malathion $0,8 \%$, kematian nyamuk uji $<80 \%$, sedangan untuk Lamdacyhalotrin 0,03\% Desa Kedungrandu dinyatakan rentan, kematian nyamuk uji 99\%-100\% dan Desa Sidamulih dinyatan toleran, kematian nyamuk uji 80\%-98\%. Disarankan mengganti insektisida golongan Phyretroid jenis Lamdacyhalotrin 0,03\%, sehingga masih dapat dipastikan kandidat penggantinya masih dalam status rentan.
\end{abstract}

Kata kunci: Demam Berdarah; Insektisida; Resistensi

\begin{abstract}
Background dengue Hemorrhagic Fever is caused by one of four different antigens, but very close to each other. Insecticides are used in vector control chemically, but this method causes the mosquito to become resistant. This research wasaimed to know the resistance status of Aedes Sp mosquitoes as the main vector of DHF in Kedungrandu Village Patikraja Subdistrict and Sidamulih Village Rawalo Subdistrict of Banyumas Regency against Malathion Insecticide 0,8\% and Lamdacyhalotrin 0,03\%. This researchdesign exploration. The research results of resistance test using Susceptibility test method with Malathion insecticide 0,8\% in Kedungrandu Village Patikraja Subdistrict showed the percentage of mosquito deaths is $8,75 \%$, and in Sidamulih Village is $15 \%$ and 11,25\%. While Lamdacyhalotrin 0.03\% in Kedungrandu Village is 100\%, and in Sidamulih Village is 92,5\%.It is conclude was resistant in both villages to Malathion $0.8 \%$, death mosquito test $<80 \%$. While for Lamdacyhalotrin $0,03 \%$ in Kedungrandu Village stated susceptible, death mosquito test $99 \%-100 \%$ and in Sidamulih Village expressed tolerant, death mosquito test $80 \%-98 \%$. Recommended replacing Phyretroid type insecticide Lamdacyhalotrin 0,03\%, so it is still certain that the successor candidate is still in vulnerable status.
\end{abstract}

Keywords: Dengue Fever;Insecticide; Resistence 


\section{Pendahuluan}

Demam dengue disebabkan oleh salah satu dari empat antigen yang berbeda, tetapi sangat dekat satu dengan yang lain, yaitu DEN-1, DEN-2, DEN-3, dan DEN-4 dari genus Flavivirus (Harwood \& James, 1979). Demam berdarah dengue (DBD) adalah bentuk dengue parah, berpotensi mengakibatkan kematian (Dantje $\mathrm{T}$ Sembel, 2009).

Virus dengue berada dalam darah (Viremia) penderita selama masa periode intrinsic 3 - 14 hari (rata-rata 4 - 7 hari). Virus akan masuk ke dalam tubuh nyamuk/ vektor pada saat nyamuk menghisap darah penderita. Pada suhu $30^{\circ} \mathrm{C}$, di dalam tubuh nyamuk Aedes Sp memerlukan waktu 8-10 hari untuk menyelesaikan masa inkubasi extrinsic dari lambung sampai ke kelenjar ludah nyamuk (Depkes RI, 2007).

Insektisida digunakan dalam upaya pengendalian vektor DBD di daerah endemis DBD. Pada sebagian kabupaten bermasalah DBD, insektisida digunakan secara selektif yang salah satunya karena keterbatasan anggaran yang tersedia dari dana APBD, tetapi beberapa kabupaten menggunakan insektisida untuk pengendalian vektor DBD, karena kebutuhan program. Golongan Organophosphat yang sering dipakai adalah Malathion dan golongan Synthetic Pyrethroid yang sering digunakan adalah lamdacyhalotrin, Sipermethrin (Sunaryo, dkk, 2014).

Tujuan penelitian adalah untuk mengetahui status resistensi nyamuk Aedes $S p$ sebagai vektor utama DBD dii Desa Kedungrandu Kecamatan Patikraja dan di Desa Sidamulih Kecamatan Rawalo Kabupaten Banyumas terhadap insektisida Malathion 0,8\% dan Lamdacyhalotrin 0,03\%.

\section{Bahan dan Metode}

Jenis penelitian adalah eksplorasi karena belum pernah dilakukan penelitian yang menggambarkan derajat resistensi nyamuk Aedes $S p$ di Desa Kedungrandu, Kecamatan Patikraja, dan di Desa Sidamulih, Kecamatan Rawalo, Kabupaten Banyumas terhadap insektisida Malathion 0,8\% dan Lamdacyhalotrin 0,03\%. Populasi adalah keseluruhan rumah di Desa Kedungrandu Kecamatan Patikraja dan Desa Sidamulih Kecamatan Rawalo Kabupaten Banyumas. Sampling penelitian adalah setiap rumah yang terdapat larva dan telur nyamuk Aedes $S p$ dengan jarak 100 meter dari rumah indeks kasus pada setiap arah mata angin. Pengumpulan dan pengukuran menggunakan instrumen ovitrap, ovistrip, paper cup, susceptibility tes kit dan Thermohygrometer, Hasil pengukuran dianalisis menggunakan soft ware, analisis data menggunakan analisis univariat.

\footnotetext{
1) E-mail: azizatul.liana@yahoo.com

${ }^{2)}$ E-mail: arissantjaka@gmail.com

3) E-mail: melafirdaust.airlangga@ gmail.com
}

3. Hasil dan Pembahasan

a. Prevalensi Kasus DBD

Analisis prevalensi dilakukan untuk mengetahui seberapa sering kasus DBD terjadi di Desa Kedungrandu, Kecamatan Patikraja, dan Desa Sidamulih, Kecamatan Rawalo, perhitungan didapatkan dari jumlah kasus dibagi jumlah penduduk kemudian dikalikan dengan 100\%. Tahun 2015 Puskesmas Patikraja adalah 0,06, sedangkan tahun 2016 Puskesmas Rawalo adalah 0,10, ini berarti terdapat 0,06 kasus yang terjadi per 7.651 populasi penduduk Desa Kedungrandu dan 1,10 kasus terjadi per 6.831 populasi penduduk Desa Sidamulih.

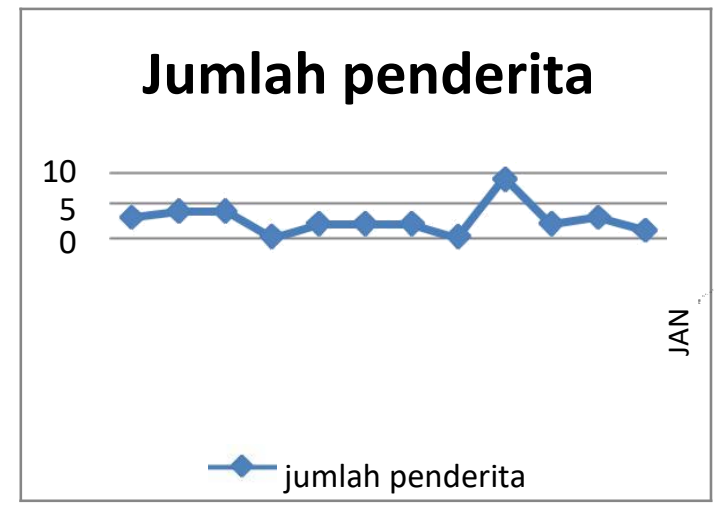

Gambar 1. Data Bulanan Kasus DBD di Desa Kedungrandu Tahun 2015 (Sumber: Data Puskesmas Patikraja Tahun 2015)

Berdasarkan karakteristik waktu kasus DBD di kedua desa menunjukkan terdapat perbedaan bulan dengan jumlah kasus tertinggi, bulan September merupakan bulan dengan jumlah kasus tertinggi di Desa Kedungrandu, Kecamatan Patikraja, karena bionomik dan lingkungan yang lebih terbuka, terdapat kebun, sungai dan semak belukar.

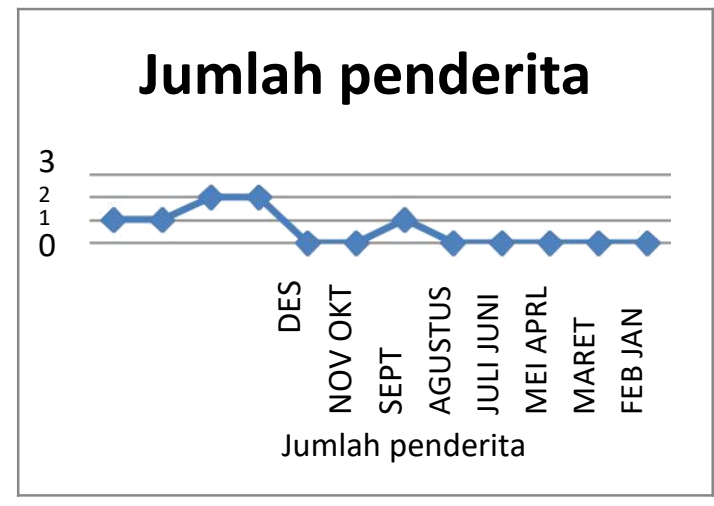

Gambar 2. Data Bulanan Kasus DBD di Desa Sidamulih Tahun 2016

(Sumber: Data Puskesmas Rawalo Tahun 2016) 
Bulan Maret dan April merupakan bulan dengan jumlah kasus tertinggi di Desa Sidamulih, Kecamatan Rawalo. berdasarkan data terdapat variasi rata-rata curah hujan di setiap kecamatan Kabupaten Banyumas. Karakteristik waktu merupakan hal yang cukup penting dalam menentukan definisi kasus dan komponen dasar dalam menentukan penyebab. Hal tersebut dikarenakan timbulnya penyakit dapat berubah setiap waktu. Kasus DBD meningkat pada bulan Desember-April dan diimbangi dengan meningkatnya curah hujan pada bulan tersebut (Boewono, D.T, dkk, 2012, dalam Rika Kurniawati, dkk, 2015).

Penularan DBD meningkat pada musim penghujan ketika suhu dan kelembaban udara sesuai bagi terbentuknya habitat tempat berkembangbiaknya nyamuk (breeding places) dan lebih panjangnya umur nyamuk. Kondisi suhu di kedua desa tersebut masih memungkinkan nyamuk untuk berkembangbiak, sedangkan suhu rata-rata optimum untuk perkembangan nyamuk adalah $25^{\circ}-27^{\circ} \mathrm{C}$. Pertumbuhan nyamuk akan terhenti bila suhu kurang dari $10^{\circ} \mathrm{C}$ atau lebih dari $40^{\circ}$ C (Ditjen PP\&PL, 2001, dalam Rahmayanti Amini, 2017).

Penyajian materi Aris Santjaka pada Seminar Nasional 2016 menyebutkan bahwa nyamuk tidak tahan pada suhu $33^{\circ} \mathrm{C}$ (Manson's, 2009), karena siklus ekstrinsik agen terganggu pada tubuh nyamuk, sedangkan hasil penelitian dengan menggunakan estimasi $33,69^{0} \mathrm{C}$ dengan catatan sinar matahari masuk ke permukaan tanah, sehingga mengurangi kelembaban, karena nyamuk termasuk binatang berdarah dingin, sehingga metabolisme dan siklus kehidupannya tergantung pada suhu lingkungan, pengaturan suhu tubuh sangat tergantung pada lingkungannya (Aris Santjaka, 2013).

Peran suhu yang cukup besar terkait dengan sistem pernafasan nyamuk itu sendiri, dimana sistem pernafasan menggunakan sistem trachea yaitu alat pernafasan yang dimiliki oleh nyamuk yang bermuara pada spiracle yaitu lubang kecil berdiameter 1 mm. Spiracle akan tertutup saat nyamuk sedang beristirahat dan terbuka sesaat jika dibutuhkan, namun jika nyamuk terbang justru spiracle akan terbuka. Tertutupnya spiracle saat istirahat dimaksudkan supaya nyamuk tidak kekurangan banyak cairan, karena nyamuk tidak mempunyai regulator untuk

mempertahankan kelembaban tubuhnya, sehingga kelembaban tubuh nyamuk sangat tergantung pada kelembaban lingkungan sekitarnya (Depkes R.I, 2007). Nyamuk tidak mempunyai pembuluh darah tetapi haemolymph atau cairan yang terdiri dari asam amino, lemak protein, glukosa dll, cairan inilah yang berfungsi menjaga kelembaban tubuh nyamuk, sehingga jika terjadi ketidak seimbangan elektrolit sedikit saja akan mengalami dehidrasi dan nyamuk akan mati (Aris Santjaka, 2013).

Penyakit DBD juga dapat menyerang semua kelompok umur baik laki-laki maupun perempuan. Hal tersebut dikarenakan munculnya kasus DBD berkaitan dengan kondisi lingkungan dan perilaku. Aktivitas rutin sehari-hari dengan rata-rata berada di dalam gedung atau ruang sekolah, mobilitas tinggi dan banyak bertemu dengan orang lain lebih meningkatkan resiko terkena gigitan nyamuk Aedes $S p$, sehingga terjadi multibitting (Djati, A.P, dkk, 2012, dalam Rika Kurniawati, dkk, 2015).

Desa Kedungrandu merupakan dataran rendah dan pegunungan dengan ketinggian 72 meter di atas permukaan laut dengan suhu masih dalam batas normal (rata-rata suhu $32^{\circ} \mathrm{C}$ ). Areal persawahan mendominasi keadaan/ fungsi tanah di Desa Kedungrandu. Desa Sidamulih merupakan wilayah Kecamatan Rawalo, Kabupaten Banyumas, Provinsi Jawa Tengah, dengan luas wilayah Desa Sidamulih $842,30 \mathrm{Ha}$ atau $8,423 \mathrm{~km}^{2}$, sebagian besar wilayah Desa Sidamulih merupakan persawahan dan ladang kering dengan iklim sama dengan rata-rata di Jawa tengah, sehingga kondisi geografis kedua desa tersebut dapat mempengaruhi kejadian DBD, ketinggian di Desa Kedungrandu masih kurang dari $1.000 \mathrm{~m}$ dan sangat memungkinkan menjadi tempat perkembangbiakan nyamuk, karena Aedes Sp dapat hidup dan berkembang biak sampai ketinggian daerah \pm 1.000 mdpl. Pada ketinggian diatas $\pm 1.000 \mathrm{mdpl}$, suhu terlalu rendah, sehingga tidak memungkinkan nyamuk berkembang biak (Soegeng Soegijanto, 2008).

b. Potensi Penularan Tabel

1. Indeks Ovitrap

\begin{tabular}{llccc}
\hline No. & Desa & $\begin{array}{c}\text { CI } \\
(\mathbf{\%})\end{array}$ & $\begin{array}{c}\text { HI } \\
(\mathbf{\%})\end{array}$ & $\begin{array}{l}\text { BI } \\
(\mathbf{\%})\end{array}$ \\
\hline 1. & Kedungrandu & 77,7 & 25 & 35 \\
2. & Sidamulih & 55,5 & 7,69 & 12,8 \\
\hline & Ratio & 1,4 & 3,25 & 2,73 \\
\hline
\end{tabular}

Sumber : Aris Santjaka 2017

Berdasarkan tabel diatas menunjukkan bahwa kepadatan dan persebaran larva pada Desa Kedungrandu lebih tinggi dari Desa Sidamulih. Survey larva menggunakan metode single larva yaitu dengan cara mengambil larva di setiap

tempat-tempat penampungan air yang ditemukan larva, dengan ditemukannya larva menunjukkan dalam rumah tersebut terdapat nyamuk Aedes $S p$, karena nyamuk tersebut bersifat domestik, sehingga untuk meletakkan telur akan mencari tempat perindukan terdekat yaitu yang terdapat di dalam rumah maupun sekitar rumah itu sendiri. Densitas atau kepadatan larva Aedes Sp pada suatu wilayah dapat menjadi ancaman bagi kesehatan masyarakat jika terjadi kontak langsung dengan manusia. Kontak nyamuk Aedes $S p$ dengan penderita DBD akan menyebabkan nyamuk terinfeksi dan jika menggigit manusia sehat dapat menyebabkan terjadinya penularan DBD (Dyah Widiastuti, Bina Ikawati, 2016). Transmisi virus 
dengue dapat terjadi secara horisontal dan vertikal, transmisi horizontal melalui siklus manusianyamuk-manusia. Transmisi diinisiasi dengan kontak antara nyamuk dengan manusia positif dengue. Selain transmisi secara horizontal, transmisi secara vertikal juga dapat terjadi. Pada proses transmisi secara vertikal tidak diperlukan terjadinya kontak antara nyamuk dan manusia infektif. Bentuk yang paling umum dari transmisi vertikal adalah transmisi transovari yang terjadi pada saat virus memasuki tubuh nyamuk, menginfeksi ovari lalu menginfeksi telur. Dengan demikian keturunan nyamuk yang menetas akan mengandung virus yang sama dengan yang menginfeksi induknya. Hal ini yang menyebabkan keberadaan virus dengue tetap terpelihara di lingkungan, sehingga menyebabkan kejadian DBD tetap ada (Epiosa M, dkk, 2014 dalam Dyah Widiastuti, dkk, 2016).

Resistensi terjadi karena penggunanan insektisida jenis tertentu dengan frekuensi tertentu, terutama fogging focus pada wilayah dengan kasus KLB (WHO, 2003, dalam Shinta, dkk, 2008). Dengan bertambahnya jumlah kasus DBD, maka jumlah fogging focuss juga ditingkatkan. Berdasarkan hasil informasi dari petugas kesehatan diperoleh keterangan bahwa frekuensi fogging focus di kedua desa menggunakan insketisida yang sama yaitu Cypermetrin golongan Pyretroid di Desa Kedungrandu telah dilakukan sebanyak 8 kali, sedangkan di Desa Sidamulih dilakukan sebanyak 4 kali dalam 3 tahun terakhir. Hal tersebut berkaitan dengan hasil perhitungan $\mathrm{HI}, \mathrm{CI}$, $\mathrm{BI}$, yang menunjukkan bahwa kepadatan dan persebaran larva pada Desa Kedungrandu lebih tinggi, sehingga potensi penuarannya lebih tinggi didukung dengan hasil kepadatan jentik (density figure) dihitung berdasarkan nilai CI, HI, BI yang dikategorikan menjadi kepadatan rendah, sedang dan tinggi menggunakan kriteria dari (Queensland Government, 2011, dalam Arum Sih Joharina,Widiarti, 2014), dinyatakan bahwa kategori Desa Kedungrandu termasuk tinggi, sedangkan kategori Desa Sidamulih sedang, sehingga potensi penularan lebih besar di Desa Kedungrandu.

Pemberantasan Sarang Nyamuk/ PSN merupakan salah satu tindakan yang harus dilakukan secara rutin karena tindakan $3 \mathrm{M}$ plus pada kedua desa masih jarang dilakukan. Notoatmodjo pada tahun 2007 menyebutkan bahwa perilaku masyarakat mempunyai

pengaruh terhadap lingkungan karena lingkungan merupakan lahan untuk perilaku tersebut (Notoatmodjo S, 2007, dalam Ayu Azlina, dkk, 2016).

Lebih dari $90 \%$ nyamuk Aedes aegypti beristirahat di tempat-tempat yang tidak terkena sinar, yaitu tempat-tempat di dalam rumah yang gelap dan tersembunyi, ruangan yang lembab, kamar tidur, kloset, kamar mandi dan dapur. Tempat istirahat di dalam rumah yang paling disukai nyamuk adalah di bawah meja kursi, baju dan korden yang tergantung dan pada dinding
(Soedarto, 2012). Setelah beristirahat nyamuk akan menghisap darah manusia kembali sampai nyamuk tersebut cukup darah untuk pematangan sel telurnya, jika nyamuk yang istirahat pada pakaian menggantung tersebut menghisap darah penderita demam berdarah dan selanjutnya pindah menghisap orang yang sehat, maka dapat tertular virus DBD (Epinosa, dkk, 2005 dalam Dyah Widiastuti, dkk, 2016).

\section{c. Resistensi}

Mekanisme resistensi merupakan mekanisme yang beragam dan kompleks pada vektor ataupun pada agen penyakit, secara teoritis dapat dijelaskan melalui mekanisme biomolekuler, biomolekuler melihat resistensi dari sisi yang terjadi pada rangkaian molekul baik di dalam sel maupun kromosom. Penyakit yang ditularkan melalui vektor mengalami double burden, beban pertama berupa tekanan di manusia yaitu dengan menggunakan obat-obatan, beban kedua terletak di tubuh nyamuk yaitu berupa harus menghadapi jenis insektisida yang sudah dipaparkan dalam waktu yang cukup lama (Aris Santjaka, 2016).

Uji Susceptibility dilakukan pada tanggal 10 dan 21 Novenber 2018 dengan suhu ruang uji antara $24^{0} \mathrm{C}$ hingga $25^{0} \mathrm{C}$ dan kelembaban $63 \%$. Pengukuran dilakukan setiap 5 menit sekali selama satu jam, hal tersebut dilakukan untuk melihat efek knockdown yaitu menimbulkan efek pingsan pada serangga. Bagi nyamuk yang kebal setelah pingsan akan pulih kembali. Nyamuk yang kebal akan menghasilkan keturunan yang mempunyai pengalaman kontak dengan golongan Piretroid, dengan demikian keturunan tersebut mempunyai proses adaptasi terhadap insektisida dengan detoksifikasi (WHO, dalam Shinta, dkk, 2008).Hasil di atas menunjukkan bahwa rata-rata prosentase nyamuk pingsan Lamdacyhalotrin 0,03\% lebih tinggi dari Malathion 0,8\%, hal tersebut itu dapat terjadi karena nyamuk uji belum pernah terpapar dengan Lamdacyhalotrin 0,03\%, meskipun kedua desa sudah pernah terpapar dengan Cypermetrin yang merupakan sama-sama golongan Phyretroid. artinya jika gugus kimia berbeda mempunyai efek yang berbeda pula. Sementara Malathion 0,8\% tidak terlihat efek knockdown dan baru terlihat setelah holding 24 jam.

Prosentase kematian rata-rata nyamuk uji setelah pengamatan selama 24 jam insektisida Malathion 0,8\% di kedua desa pada tabel diatas menunjukkan kategori resisten. Malathion pada serangga bekerja sebagai racun syaraf dan berakibat otot pada tubuh serangga mengalami kejang, kemudian lumpuh, dan akhirnya mati (Kasumbogo, 2004, dalam Odentara Sembiring 2009).

Prosentase kematian rata-rata nyamuk uji setelah pengamatan selama 24 jam insektisida Lamdacyhalotrin 0,03\% di Desa Kedungrandu. Pada tabel menunjukkan kategori rentan, sedangkan pada Desa Sidamulih pada tabel di atas menunjukkan kategori toleran. Kecepatan laju 
resistensi Lamdacyhalotrin tergatung dari tingkat tekanan seleksi yang diterima oleh populasi serangga. Frekuensi alel individu rentan/ peka di alam sebetulnya lebih besar di bandingkan frekuensi alel individu resisten dan frekuensi alel homozigot berkisar 10-2 hingga 10-13, karena seleksi yang terus menerus jumlah individu peka dalam sesuatu populasi akan semakin sedikit dan meninggalkan individu resisten (Widiarti, dkk, 2011). Kedua insektisida tersebut yang paling resisten adalah Malathion 0,8\%, karena telah digunakan dalam jangka waktu yang panjang dan frekuensi yang tinggi ditambah lagi dengan pengunaan insektisida rumah tangga sehari-hari, meskipun sudah jarang terpapar Malathion, populasi Aedes $S p$ di kedua desa tersebut masih menurunkan sifat resisten terhadap insektisida ini, karena semua golongan Organofosfat memiliki mekanisme kerja yang hampir sama yaitu menghambat kerja enzim asetilkolinesterase (Sunaryo NP, 2013, dalam Dyah Widiastusi, Bina Ikawati, 2016).

Malathion $0,8 \%$ telah digunakan sebagai insektisida sejak tahun 1991. Berdasarkan data dari Dinas Kesehatan Banyumas dari tahun 2010 sampai dengan 2014 telah dilakukan 330 kali pelaksanaan fogging focus di Kabupaten Banyumas dimana lebih dari $50 \%$ atau 183 kali diantaranya menggunakan insektisida Malathion 0,8\%. Dari total fogging focus dengan insektisida jenis Malathion 0,8\% di Kabupaten Banyumas dari tahun 2010 sampai 2014, 43\% atau 78 kali diantaranya dilakukan di Kota Purwokerto (Dinas Kesehatan Banyumas, 2014, dalam Irawan Endy Pratama, 2016). Menurut teori rotasi penggunaan insektisida, maka Malathion 0,8\% dapat digunakan lagi, tetapi menurut hasil penelitian resistensi bersifat permanen karena mutasi genetik.

\section{Simpulan dan Saran}

Simpulan: Nyamuk Aedes $\mathrm{Sp}$ terhadap insektisida Malathion 0,8\% di Desa Kedungrandu dan Desa Sidamulih dinyatakan resisten karena kematian nyamuk uji $<80 \%$, sedangkan insektisida Lamdacyhalotrin $0,03 \%$ Desa Kedungrandu dinyatakan rentan karena kematian nyamuk uji 99\%-100\%, dan Desa Sidamulih dinyatan toleran karena kematian nyamuk uji 80\%-98\%.

Saran: Perlu dilakukan pencarian insektisida pengganti dari golongan lain, misalnya dari golongan Phyretroid jenis Lamdacyhalotrin 0,03\%, sehingga masih dapat dipastikan kandidat penggantinya masih dalam status rentan.

\section{Daftar Pustaka}

Adang Iskandar, Chasan Sudjain, dkk. 1985. Pemberantasan Serangga \& Binatang pengganggu. Departemen kesehatan RI

Aris Santjaka. 2013. Malaria Pendekatan Model kausalitas. Yogyakarta: Nuha Medika.
Aris Santjaka. 2016. Zika dalam Perspektif vektor dan Upaya Pengendaliannya. Makalah dipresentasikan pada Seminar Nasional Jurusan Kesehatan Lingkungan Purwokerto Politeknisk Kesehatan semarang, Purwokerto 19 November 2016

Arum Sih Joharina, Widiarti. 2014. Kepadatan Larva Nyamuk Vektor sebagai Indikator Penularan Demam Berdarah Dengue di daerah Endemis di Jawa Timur. Salatiga: Baai Besar Litbang Vektor dan Reservoir Penyakit, Badan Litbang Kesehatan Kementerian Kesehatan RI. at http://ejournal.litbang.depkes.go.id, diakses pada 20 April 2018

Ayu Azlina, Adrial, Eliza Anas. 2016. Hubungan Tindakan Pemberantasan sarang Nyamuk dengan Keberadaan Larva Vektor DBD di Kelurahan Lubuk Buaya. Padang: Universitas Andalah Padang. At http://jurnal.fk.unand.ac.id, diakses pada 5 April 2018

Ayu Yulistyawati, Sayono, Ulfa Nurullita, Status Resistensi Aedes aegypti terhadap Malathion di Kota Semarang. Semarang: Universitas Muhammadiyah semarang

Bina Ikawati, Sunaryo, Dyah Widiastuti. 2015 Peta Status Kerentanan Aedes aegypti (Linn.) terhadap Insektisida Cypermetrin dan Malathion di Jawa Tengah. At http://ejournal.litbang.depkes.go.id, diakses pada 3 Januari 2018

Chasan Sudjain Kusnadi. 2006. Pengendalian Vektor dan Binatang Pengganggu. Makassar: Instalasi Penertiban Jurusan Kesehatan Lingkungan Poltekkes Makassar

Cut Irsanya Nilam Sari. 2005. Pengaruh Lingkungan terhadap Perkembangan Penyakit Malaria dan Demam Berdarah Dengue. Bogor: Institut Pertanian Bogor. http://www.rudyct.com/PPS702ipb/09145/cut_irsanya_ns.pdf, diakses pada 3 Januari 2018

Dantje T Sembel. 2009. Entomologi Kedokteran. Yogyakarta: Andi Offset

Dantje T Sembel. 2012. Dasar-dasar Perlindungan Tanaman. Yogyakarta: Andi Offset

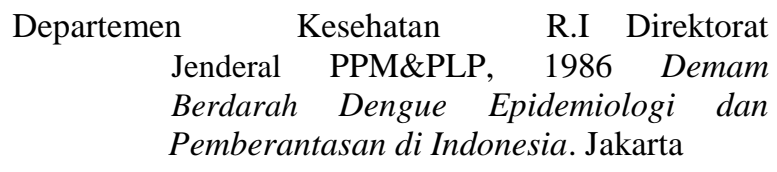

Dinas Kesehatan Kabupaten Banyumas. Profil Kesehatan Kabupaten Banyumas Tahun 2016. 2016 
Dinas Kesehatan Jawa Tengah. Profil Kesehatan Jawa Tengah Tahun 2015. 2015

Direktorat Jenderal Pengendalian Penyakit dan Penyehatan Lingkungan Departemen Kesehatan RI. 2008. Modul Pelatihan bagi Pemberantasan Sarang Nyamuk (PSN) DBDB dengan Pendekatan Komunikasi Perubahan Perilaku / KKP (Communications For Behavioral Impact / Combi. Jakarta : Dirjen PP\&PL

Direktorat Jenderal Pengendalian Penyakit dan Penyehatan Lingkungan. 2012. Pedoman Penggunaan Insektisida (Pestisida) dalam Pengendalian Vektor. Jakarta: Kementerian Kesehatan RI

DJ Gunandini dan P.B. Wicaksana. 2005. Peningkatan dan Aktivitas Enzim Asetilkolinesterase pada Nyamuk Aedes aegypti yang Diseleksi dengan Malathion. Bogor: Departemen Parasitologi dan Patologi, FKH-IPB

Dyah Widiastuti dan Bina Ikawati. 2016. Resistensi Malathion dan Aktivitas Enzim Esterase pada Populasi Nyamuk Aedes aegypti di Kabupaten Pekalongan. Banjarnegara: Balai Litbang P2B2 Banjarnegara. at https://media.neliti.com, diakses pada 3 Januari 2018

Elsa Endiyani. 2016. Kohort Densitas Nyamuk pada Fogging Focus di Desa Kedungrandu Kecamatan Patikraja Kabupaten Banyumas Tahun 2015. Purwokerto: Kementerian Kesehatan Republik Indonesia Politeknik Kesehatan Kemenkes Semarang

Firda Yanuar Pradani, Mara Ipa, Rina Marina, Yaneu Yuliasih. 2011. Status Resistensi Larva Aedes aegypty Terhadap Temefos di Tiga Kelurahan Endemis Demam Berdarah Dengue Kota Sukabumi. Ciamis: Loka Litbang P2B2 Ciamis. at http://ejournal.litbang.kemkes.go.id, Diakses pada tanggal 3 Januari 2018

Rumus Bangun Sipermetrin. At http://www.chemspider.com/Image, diakses pada 12 Januari 2018

Shinta, Supratman Sukowati, Asri Fauziah. 2008. Kerentanan Nyamuk Aedes aegypti di daerah Khusus Ibukota Jakarta dan Bogor Terhadap Insektisida malathion dan Lamcacyhalotrin. Jakarta: Universitas Negeri Jakarta. at http://ejournal.litbang.depkes.go.id, Diakses pada 3 Januari 2018
Soedarto. 2012. Demam Berdarah Dengue (Dengue Haemohagic Fever). Jakarta: CV Sagung Seto

Soegeng Soegijanto. 2008. Demam Berdarah Dengue. Surabaya: Airlangga University Press

Soekidjo Notoatmodjo. 2010. Metodologi Penelitian Kesehatan. Jakarta: Rineka Cipta

Sunaryo, Bina Ikawati, Rahmawati, Dyah Widiastuti. 2014. Status Resistensi Vektor Demam Berdarah Dengue (Aedes aegypti) terhadap malathion 0,8\% dan Permethrin $0,25 \%$ di Provinsi Jawa Tengah. Banjarnegara: Balai Litbang Pengendalian Penyakit Bersumber Binatang Banjarnegara. at http://ejournal.litbang.depkes.go.id, diakses pada 3 Januari 2018

Tri Cahyono. 2018. Panduan Penulisan Skripsi. Purwokerto: Politeknik Kementrian Kesehtan RI, Kesehatan Lingkungan

Widiarti, Bambang Heriyanto, Damar Tri Boewono, Umi Widyastuti Mujiono, Lasmiati, Yuliadi, 2011, Peta Resistensi Vektor Demam Berdarah Dengue Aedes aegypti terhadap Insektisida Kelompok Organofosfat, Karbamat, dan Pyrethroid di Propinsi Jawa Tengah dan Daerah Istimewa Yogyakarta, Salatiga: Balai Besar Penelitian dan Pengembangan Vektor dan Reservoir Penyakit Salatiga. at http://ejournal.litbang.depkes.go.id, diakses pada 3 Januari 2018

Widoyono. 2011. Penyakit Tropis (Epidemiologi Penularan, Pencegahan \& Pemberantasannya). Jakarta: Erlangga

Y. Andi Trisyono, 2006. Resistensi Serangga terhadap Insektisida, $\underline{\text { http://faperta.ugm.ac.id, diakses pada } 2}$ Novenber 2017 